\title{
EL TEATRO DE MARIONETAS EN BAJTÍN: LA CRÍTICA COMO SABOTAJE ANTE LA POLIFONÍA
}

\author{
BAKHTIN'S PUPET THEATRE: CRITICISM AS SABOTAGE \\ FACING POLYPHONY
}

\author{
Manuel ASENSI PÉREZ \\ Universitat de València-Estudi General \\ manuel.asensi@uv.es
}

Resumen: Este ensayo trata de confrontar la teoría polifónica de Bajtín con la teoría silogística del discurso propia de la crítica como sabotaje. Con esa finalidad se elige la obra de Bajtín Problemas de la poética de Dostoievski, tanto en su versión española como en la rusa. Mediante una lectura atenta, propia del sabotaje, se ponen de relieve las contradicciones del discurso de Bajtin en torno a la polifonía, el discurso ajeno, y la independencia de los personajes en relación al autor. Tales contradicciones demuestran que todos esos conceptos empleados por Bajtín en torno a Dostoievski son en realidad recursos técnicos mediante los que el autor crea un determinado mundo. La crítica como sabotaje recupera la figura del autor como figura no compacta y dividida, pero responsable de la creación de un silogismo y un modelo de mundo complejos.

Abstract: This essay aims to confront Bakhtin's polyphonic theory and syllogistic theory belonging to Criticism as Sabotage. To this end we choose 
Bakhtin's Problems of Dostoievski's Poetics, both in Spanish version and russian one. Through a close Reading, typical of the kind of criticism called Sabotage, we underline the contradictions of Bakhtin's discourse around polyphony, speech of the other, and the Independence of the characters in relation to the author. Such a contradictions show that all concepts employed by Bakhtin about Dostoievski are actually technical resources through which the Author creates a concrete wordl. Criticism as sabotaje gets back author' figure, divided in itself, but responsable for the creation of a syllogism and a complex wordl's model.

Palabras clave: Crítica como sabotaje. Bajtín. Silogismo. Dialogismo. Polifonía. Lectura atenta.

Key words: Criticism as sabotage. Bakhtin. Syllogism. Dialogism. Polyphony. Close Reading.

\section{I.}

La afirmación de que la literatura y el arte poseen una disposición silogística capaz de modelizar la subjetividad de lo/as lectore/as y espectadore/ as, no es diferente de la del resto de los discursos, pero sí más compleja (Asensi, 2011; Ferrús, 2013; Stallings, 2013, entre otros y otras), hace surgir una multiplicidad de preguntas. Una de las más importantes inquiere acerca del lugar que en un texto ocupa el silogismo y quién es su responsable (si lo hay). Pongamos un ejemplo: cuando el protagonista de Memorias del subsuelo de Dostoievski escribe en su diario «Sin embargo (estoy firmemente convencido de ello), la conciencia, toda la conciencia es una enfermedad», ¿quién sostiene esa afirmación? ¿hay algún «quién» detrás de ella? ¿es el mismo autor o es el narrador en primera persona? En una narración en tercera persona, ¿de quién depende el silogismo? ¿de un personaje? ¿del narrador? ¿de otro personaje?

Más aún: cuando Bajtín asegura que «la pluralidad de voces y conciencias independientes e inconfundibles, la auténtica polifonía de voces autónomas, viene a ser, en efecto, la característica principal de la novelas de Dostoievski» (Bajtín: 1993: 16) ${ }^{1}$, ¿no viene ello a dar al traste con la teoría silogística, sostenida por la teoría de los modelos de mundo? ¿Qué modelo de mundo, qué silogismo, son los que estructuran, por ejemplo, una novela

\footnotetext{
1 Idea fundamental del autor.
} 
como Los hermanos Karamazov, si está compuesta por las antinomias de una pluralidad de voces, cada una manteniendo una posición y una tesis? ¿Cómo se puede reconciliar el planteamiento silogístico con la síncrisis, la confrontación de diversos puntos de vista, propia del diálogo socrático y de la sátira menipea?

El objetivo de este trabajo es examinar la teoría bajtiniana sobre la literatura carnavalesca a la luz de la crítica como sabotaje. De ese examen deberían resultar dos hechos: por un lado, el sabotaje ${ }^{2}$ del planteamiento de Bajtín; y, por otro, la clarificación, mediante el procedimiento del contraste, de la teoría silogística del discurso literario. Con ese fin tomaremos como texto de referencia el libro de Bajtín, Problemas de la poética de Dostoievs$k i(1993)^{3}$, sin que ello suponga ignorar otras obras suyas fundamentales - por ejemplo, la Teoría y estética de la novela (1989), o la Estética de la creación verbal (1985), entre otras- Sin embargo, se dará prioridad a su estudio sobre Dostoievski porque en él quedan expuestos y representados, de forma clara, los grandes planteamientos del teórico ruso.

Hablar del sabotaje de los argumentos de Bajtín no supone ningún menosprecio ni destrucción de estos, sino un intento de situarlos dentro de sus posibilidades y en el nivel que les corresponde. Quizá, lo que más se pueda ver afectado en estas páginas son las lecturas que se han venido haciendo de su obra, así como sus aplicaciones. Holquist, por ejemplo, afirma que «words in literary texts are active elements in a dialogic exchange taking place on several different levels at the same time» (1990: 68), convirtiendo el principio del dialogismo en algo trascendental que afecta a cualquier obra literaria (véase también Bennet, 1978; Bialostosky, 1986, Thomson, 1984 y Haynes, 2013, etc...), sin advertir que el propio Bajtín marca la diferencia entre la literatura monológica y la dialógica. Algo semejante hará la crítica francesa que va de Barthes a Kristeva pasando por Genette y Derrida.

Sin embargo, si se lee atentamente las páginas que Bajtín dedica a este problema se observa que en esa diferencia el papel del autor es de primer orden. En la literatura monológica:

la semejanza entre los principios que emplee el autor para representar al héroe y la posición ideológica que este asume debe atribuirse a la manera

2 Otro nombre para la crítica como sabotaje, igual que ocurre con la expresión «teoría silogística».

3 Y que conoce dos versiones: la de 1929 y la de 1963 «considerablemente ampliada y complementada», según Kozhinov (1993: 18 nota al pie). 
uniacentual en que el autor acostumbra a describir los parlamentos y las vivencias del héroe (...). La palabra de este personaje se ubica así en un mismo plano con la del autor (Bajtín, 1993: 120, la cursiva es del autor).

Lo que Bajtín llama «principios» no se corresponde ni con el silogismo del texto ni con su modelo de mundo, pero forma parte de ellos, los integra. En este sentido no resulta complicado advertir que la responsabilidad de tales principios, por mucho que estén expresados por el personaje, se corresponden a los del autor (y da igual que hablemos del autor como personaje histórico que del autor como narrador, diferencia que en Bajtín está poco clara ${ }^{4}$. No tiene ningún inconveniente en hablar de Dostoievski, Turgeniev, Tolstoi o Pushkin, en tanto sujetos históricos). Desde la óptica de esta literatura monológica, la frase del protagonista de Memorias del subsuelo sobre la conciencia correspondería a la del autor. No es el caso, por supuesto, ya que precisamente esa novela es tratada por Bajtín como perteneciente a la literatura dialógica. De hecho, en el capítulo dedicado a «Las obras de Dostoievski» ya anuncia que el análisis de esta obra parte de su relación con la menipea, la anácrisis aguda y la mezcla heterogénea de temas y materiales (Bajtín, 1993: 218)5.

Frente al monologismo, el dialogismo se caracteriza, entre otras cosas, por el hecho de la no coincidencia entre los supuestos principios (la ideología, dice Bajtín) del autor y los de los personajes. El autor y el narrador se retiran, no expresan su «punto de vista», no emplean el personaje como una marioneta para transportar sus ideas. Por eso, escribe Bajtín:

Dostoievski no creaba sus ideas como las crean los filósofos o los científicos: solía crear las imágenes vivas de ideas, encontradas, oídas (...) captando [en ellas] las relaciones dialógicas entre voces, su interacción ideológica (...) Solía poner juntas tales ideas y visiones del mundo (...) y las hacía discutir (Bajtín, 1993: 128 y 130).

Lo que esto significa es que de aceptar este planteamiento resulta imposible determinar cuál es el silogismo de una novela (ya que de novela

${ }^{4}$ Graham Roberts, en su glosario de términos al final del libro The Bakthin reader, dice precisamente a propósito de la noción de «autor» en Bajtín: «The term 'author' as used by Bakhtin can refer to a flesh-and-blood person, such as Rabelais or Dostoievsky. As well as these real historical figures, however, Bakhtin sees the autor as a cognitive construct 'aesthetically' interacting with the consciousness of his or her characters» (Morris, 1994: 246).

${ }^{5} \mathrm{El}$ análisis propiamente dicho y por extenso de esta obra en la clave de obra bivocal se encuentra en las pp. 320-334. 
hablamos $)^{6}$. ¿A quién atiendo en una narración para determinar su silogismo, a lo que dice un personaje, a lo que dice otro, o a lo que dice el narrador? El clímax de este argumento se alcanza cuando Bajtín hace notar que la relación entre el narrador y el personaje llega a ser de oposición, conflicto y lucha:

La segunda voz, al anidar en la palabra ajena, entra en hostilidades con su dueño primitivo y le obliga a servir a propósitos totalmente opuestos. La palabra llega a ser arena de lucha entre dos voces (Bajtín, 1993: 270).

Ese dialogismo, esa palabra ajena, no solo se da entre los personajes, o entre el autor y el personaje, sino en el interior mismo de la conciencia de un mismo personaje. Así lo confirma el examen de Memorias del subsuelo, novela escrita en la clave de una confesión, pero en la que «la palabra ajena está presente determinando invisiblemente desde el interior el estilo del discurso» (Bajtín, 1993: 321). Así pues, esa arena de lucha (expresión esta recurrente en la obra El marxismo y la filosofía del lenguaje $)^{7}$, crea una escisión en el seno de la conciencia del personaje que parece hablar unilateralmente. La identidad de la conciencia y del discurso se escinde y se diferencia en relación consigo misma. Es a lo que se refiere Bajtín cuando señala que «nos fascina el grado extremo y agudo de la dialogización interna» (Bajtín, 1993: 320).

Esa dialogización interna entra aparentemente en contradicción con esa supuesta estructura silogística que propone la teoría de los modelos de mundo. ¿Qué podría querer decir un silogismo escindido en su propia configuración? Toda conciencia escindida (en clave psicoanalítica) debería impedir, al menos en tales casos, la constitución de un silogismo, y de un silogismo. Toda identidad está contaminada desde el principio por la diferencia que el otro y lo otro pone en el «yo» escindido y afectado (Derrida, 1967).

Es cierto que Bajtín trata de hacer extensible a la mayor parte del género novelesco los principios dialógicos, la polifonía, la palabra ajena y bivocal. En el capítulo dedicado a la génesis histórica de las novelas de Dostoievski,

\footnotetext{
6 Para una ampliación de la idea de silogismo en la literatura véase Asensi (2012).

7 La unidad de estilo, así como la unidad de conceptos e ideas debería impedir pensar en Voloshinov como algo diferente de la firma de un texto escrito por Bajtín. Baste esta cita (podrían ser muchas) para demostrarlo: «Así las distintas clases sociales usan una misma lengua. Como consecuencia, en cada signo ideológico se cruzan los acentos de orientaciones diversas. El signo llega a ser la arena de la lucha de clases» (Voloshinov, 1992: 49. La cursiva del autor).
} 
no habla de la obra de un autor, sino del «género novelesco», que de acuerdo con sus investigaciones posee «tres raíces principales: la epopeya, la retórica y el carnaval» (Bajtín, 1993: 154). De hecho, en 1941 subraya cómo uno de los rasgos fundamentales de la novela en tanto género «la tridimensionalidad estilística relacionada con la conciencia plurilingüe que se realiza en ella» (Bajtín, 1989: 456). En ese mismo ensayo deja entrever que también hay novelas «con un solo plano» (Bajtín, 1989: 454), pero especialmente a partir del siglo XVIII, la novela polifónica se convierte en predominante. Esa es la razón por la que los estudiosos de la literatura se habrían sentido impotentes ante ese anti-género (cf. José Romera et alii, 1995). La resistencia de un texto novelesco a la teoría silogística no proviene únicamente de novelas como la de Dostoievski, sino que sería extensible a una buena parte de la novela de los últimos tres siglos.

Sin embargo, vamos a demostrar en lo que sigue que la teoría de Bajtín posee unos límites que nos van a permitir explicar con más detalle el funcionamiento del silogismo en la literatura y especialmente en la novela. Dichos límites surgen de determinadas contradicciones en sus argumentos que, por paradójico que pueda parecer, tienen su origen en el extremo rigor con el que analiza la obra de Dostoievski.

Un primer síntoma lo encontramos justo en los inicios de su estudio de Memorias del subsuelo. En alusión a los comienzos de esta novela Bajtín escribe: «En las primeras palabras de la confesión la polémica interna con el otro aparece oculta. Pero la palabra ajena está presente determinando invisiblemente desde el interior el estilo del discurso» (Bajtín, 1993: 321).

Lo que llama la atención en esta cita es el término «estilo», porque a través de él Bajtín pone de relieve que un texto literario como la novela es el resultado de una determinada manipulación. Nada descubrimos al decir que desde su etimología, el estilo es siempre la presión de un objeto puntiagudo, de un puñal, estilete o pluma que puede dejar un sello, marca o forma (Derrida, 1981: 27). A este respecto, cambia poco que se maneje un concepto antiguo de «estilo» («conjunto de rasgos o caracteres que permiten constituir una categoría fija») o uno moderno (manifestación «de la actitud personal del artista en un momento dado») (Lázaro Carreter, 1953: 115).

En cualquier caso, y como ha puesto de relieve la estilística de diversas orientaciones, el estilo está vinculado a alguna forma de desvío (Guiraud, 1969: 27-47). Por ello, aunque Bajtín asegure que «la palabra ajena» determina el estilo del discurso, dando a entender que un otro exterior viene a configurar un estilo determinado, resulta cuanto menos sospechosa la pasi- 
vidad atribuida a quien ha escrito «Tengo cuarenta años, y cuarenta años son toda la vida...etc.».

Da la impresión de que Dostoievski haya sido asaltado por la palabra ajena como por una musa y su mano se haya visto llevada a escribir tales confesiones. ¿Reproduce la palabra ajena bajo otro nombre aquello que Platón dice acerca del efecto del entusiasmo bajo el que escribe el poeta? ${ }^{8}$ Sabemos que no es así, porque a pesar de que Bajtín polemizara con el marxismo, sus planteamientos están dentro del marco marxista. No obstante, tanto en el caso platónico como en el caso de Bajtín se está presuponiendo una determinada pasividad del autor en el momento de su escritura. En el fragmento citado del teórico ruso queda muy claro que quien determina el estilo del discurso es la palabra ajena. Y aunque en este caso hable de la «palabra ajena» es claro que se trata de las «palabras ajenas». Podría interrogarse la cercanía de este planteamiento al del Lacan de «la instancia de la letra en el inconsciente o la razón desde Freud» (Lacan, 1983: 179-216), y se hará a su debido tiempo, pero por el momento sigamos de cerca a Bajtín en su argumento.

La fuente de la palabra ajena en Dostoievski las halla Bajtín bien en la realidad misma, bien en prototipos extraídos de diferentes textualidades. Este tenía el «don genial de oír el diálogo de su época o, más exactamente, de escuchar a su época como un diálogo enorme» (Bajtín, 1993: 128). En repetidas ocasiones, alude Bajtín al oído y a la vista del escritor. En el capítulo titulado «La idea en Dostoievski» lo menciona en diversos momentos ${ }^{9}$. Otro origen de la palabra ajena lo encontraba en otros autores, en Max Stirner, Napoleón III, Chaadáiev y Herzen.

Llegados a este punto, no es de extrañar que tanto Dostoievski como el narrador desaparezcan. A diferencia del discurso uniacentual en el que las ideas de los personajes se ubican en el mismo plano que las del autor, en el discurso polifónico de Dostoievski la idea ajena se preserva, guarda la distancia en relación al autor, «sin afirmarla y sin fundirla con su propia ideología expresa» (Bajtín, 1993: 121). El autor se presenta enfrentado al personaje, sin el poder de iluminar plenamente el mundo representado en su

\footnotetext{
8 «Y cada poeta depende su musa respectiva. Nosotros expresamos esto, diciendo que está poseído, o lo que es lo mismo que está dominado» (Ión, 536 a-b).

9 «ideas encontradas, oídas, a veces adivinadas» (128), «trataba de oír también las voces del futuro» (129), «sabía oír o adivinar en la realidad existente» (129), «ese material son voces y puntos de vista ajenos» (142), etc.
} 
novela. Su palabra es palabra entre otras palabras, «postura entre otras posturas» (Bajtín, 1993: 140).

No quiere decir otra cosa la expresión «palabra bivocal»: en Dostoievski la escritura se orienta tanto hacia el objeto del discurso, como hacia el discurso ajeno, y al rozar lo ajeno se multiplica, se diversifica y entra en contradicciones. Todo ello, insistimos, supone que el lector no ve el discurso del autor porque permanece escondido: «El autor no nos muestra su discurso [...] sino que lo utiliza para sus fines desde el interior, obligándonos a percibir claramente la distancia entre sí mismo y esta palabra ajena» (Bajtín, 1993: 266). Por eso asegura Bajtín que en tales novelas no hay argumento, pues su tema principal es «la misma orientación del hombre con respecto a la palabra y a la conciencia ajena» (290). La conclusión es clara:

En las novelas de Dostoievski todo se reduce al diálogo, a la contraposición dialógica en tanto que centro. Todo es tan solo recurso, el diálogo es la finalidad propia. Una sola voz no concluye ni resuelve nada. Dos voces es un mínimo de vida, un mínimo de ser. En la concepción de Dostoievski, la infinitud potencial del diálogo ya de por sí resuelve el problema acerca de que ésta no puede tener argumento... (Bajtín, 1993: 355) ${ }^{10}$.

Ya en los texto recogidos en la Estética de la creación verbal, que recogen una buena cantidad de trabajos de Bajtín entre 1919 y 1974, al tratar el tema de la relación entre el autor y el personaje, señala que dicha relación se caracteriza por «una intensa extraposición del autor con respecto a todos los momentos que constituyen al personaje» (Bajtín, 1985: 21). Dada, pues, la autonomía del héroe tanto en relación al autor como en relación a otros personajes, dada la polifonía que caracteriza sus novelas, ¿quién será el sostén del silogismo en tal clase de novelas? ¿De quién depende? ¿A qué voz, de entre todas, nos dirigimos para averiguar la construcción silogística de ese texto? Sin duda alguna, esta teoría de Bajtín es una de las que supone un mayor reto a la teoría silogística de la literatura, al menos en apariencia.

10 Por la importancia de esta frase resulta necesario citar el original ruso: «Bce в романах Достоевского сходится к диалогу, к диалогическому противостоянию, как к своему центру. Все- средство, диалог- цель. Один голос ничего не кончает и ничего не разрешает. Два голосаминимум жизни, минимум бытия» (1979: 372). 


\section{II.}

Los hechos no son tan sencillos, sin embargo, ni en relación a la teoría de Bajtín, que hemos tratado de forma muy condensada, ni en relación al problema del silogismo en textos tan complejos como son las «novelas». Hay que aclarar que el silogismo o silogismos de un texto literario no depende(n) de una voz que transmita de forma unilateral su ideología, bien en nombre propio, bien por boca de algún personaje. El silogismo tiene su origen en, y a la vez origina, un modelo de mundo, del que el lector saca un conjunto de conclusiones. Naturalmente, el responsable de ese modelo de mundo es el autor o autora, no como un sujeto compacto y consciente, sino como alguien que ejerce la manipulación de un material que le pre-existe. Igualmente sería erróneo hablar del modelo de mundo de un autor o autora, porque aunque esto sea cierto en virtud de un acto de re-enunciación, los modelos de mundo también le pre-existen. La teoría de los modelos de mundo se niega a prescindir de la figura del autor porque la ideología que lo atraviesa, sus fuerzas en conflicto, dan lugar, mediante lo que Mukarovski (1977) denominaba «gesto semántico», a un determinado modelo de mundo.

Así, lo que se aprecia en el libro de Bajtín, objeto de análisis, es que él tampoco puede prescindir de esa figura del autor Dostoievski. Adelantemos la siguiente hipótesis de trabajo: todo lo que Bajtín describe bajo el nombre de polifonía, discurso ajeno, palabra bivocal, enfrentamiento entre autor y personaje, pertenece a un plano técnico y en nada afecta a la realidad del hecho literario como totalidad. Se halla en un plano semejante al del metalenguaje narratológico de G. Genette (1989) cuando escribe sobre Proust. El estudio de Bajtín tiene como objetivo los mecanismos literarios y formales propios de la obra de Dostoievski, pero ello no logra ocultar en absoluto un hecho esencial: que en última instancia es el autor quien habla, el autor como espacio cruzado por diferentes fuerzas.

En la cita anterior de la página 355 de su libro lo expresa voluntaria o involuntariamente: ¿Qué puede significar si no la frase «todo es tan solo un recurso» (Все- средство)? El ruso sustituye el verbo «ser» por el guión (hecho del que Heidegger sacó muchas consecuencias) y literalmente dice en su lengua «todo es recurso (medio)». La traducción española (de Tatiana Bubnova) hiperboliza el sentido ruso al añadir ese «tan solo». Ante ello, no puede evitarse el que esta idea sobre el «recurso» (средство) quede relacionada con la de «procedimiento» de la que hablaban Sklovski y los formalistas rusos (Todorov, 1965: 76-97). La proximidad en ruso entre седство (recurso) у приём (procedimiento) es notable, dado que prácticamente son 
sinónimas. Ambas pueden ser traducidas como «medio», «procedimiento», «recurso» (Sadikov: 2010). Vale la pena recordar una de las frases en que Sklovski emplea la palabra приём:

Целью искусства является дать ощущение вещи, как видение, а не как узнавание; приёмом искусства является приём "остранения» вещей и приём затруднённой формы, увеличивающий трудность и долготу восприятия, так как воспринимательный процесс в искусстве самоиелен и должен быть продлён; искусство есть способ пережить деланье вещи, а сделанное в искусстве не важно ${ }^{11}$ (1983: 12).

Ese desliz, más o menos intencional, de Bajtín es verdaderamente significativo puesto que la palabra ajena, que sin duda opera en la constitución misma del signo, no supone que Stavroguin, por ejemplo, hable de verdad por sí mismo como si de un ente de carne y hueso se tratara, sino que el autor utiliza el recurso (средство о приём) de presentar a Stavroguin como independiente del autor. Tal independencia no es una realidad, es un procedimiento, un medio (dice en ruso, insistamos) para alcanzar un objetivo estético determinado. No debe sorprender, por ello, que justo en el momento en que Bajtín diga que Dostoievski sabía ver y oír en la realidad misma o en otras obras esas voces enfrentadas, afirme al mismo tiempo que «Dostoievski no copiaba ni describía sus prototipos sino que solía reelaborarlos libre y creativamente en imágenes de las ideas artísticamente vivas» [Bajtín, 1993:130) (Достоевский вовсе не копировал и не излагал эти прототипы, а свободно-творчески перерабатывал их в живые художественные образы идей... (1979: 298)].

En esta afirmación se halla el quid de la cuestión: las voces oídas aquí y allá son «reelaboradas» (перерабатьввал) por Dostoievski para que den la impresión de ser ajenas, de modo que el autor realiza el gesto de ubicar tales voces en el lugar del otro, por mucho que en realidad sea Dostoievski quien desde su lugar de sujeto hable, por ejemplo en Los hermanos Karamazov. Parece claro que esa «reelaboración» siembra muchas dudas en torno a la verdadera independencia del personaje en relación al autor.

${ }^{11}$ Es una de las afirmaciones más conocidas de Sklovski: «El fin del arte es ofrecer una sensación del objeto como visión y no como reconocimiento: el procedimiento del arte es el procedimiento de singularización de los objetos, así como el procedimiento que consiste en oscurecer la forma, en aumentar la dificultad y la duración de la percepción» (Todorov, 1965: 83). 
La prosa de Bajtín se desliza, por un lado, insistiendo en la autonomía del personaje y, por otro, dejando ver que se trata de una operación del autor. Repite el motivo de las conciencias dialógicamente cruzadas y añade: «Solía poner juntas tales ideas y visiones del mundo que en la propia realidad estarían absolutamente desunidas y sordas una respecto a otra, y las hacía discutir» (Bajtín, 1993: 130). Esta cita suscita dos cuestiones.

La primera: ¿qué diferencia una «visión del mundo» de un «modelo de mundo»? El concepto de «visión» implica una subjetividad desde la que se contempla el mundo, mientras que el de «modelo» señala el carácter objetivo de una imagen análoga a la realidad en la que vive el lector o la lectora. La «visión del mundo» carga todo el énfasis en el sujeto, mientras que el «modelo de mundo» enfatiza la totalidad de la relación autor(a)-textolector(a), al tiempo que señala su carácter apelativo, performativo y modelizador. A ello se suma otra característica, que se puso de relieve en un trabajo anterior: el carácter empírico del mundo, con su dolor, sus sufrimientos, sus alegrías «no puede dejar de lado el hecho de que un mundo es en sí mismo un modelo de mundo naturalizado, fosilizado, como historia y tomado como mundo objetivo» (Asensi, 2013: 22). Son más las diferencias, pero para el propósito de este trabajo baste con las señaladas.

La segunda: por muchas conciencias entrecruzadas que se pongan en el juego estético de la novela polifónica, el «hacer» del autor no desaparece en ningún momento. La «reelaboración» de la que hablaba anteriormente Bajtín, aquí aparece ahora bajo la forma de un «hacer» del autor que hace discutir a las ideas. Por mucho que se trate de marcar la distancia entre el autor y el personaje, por mucho que se le pretenda borrar, aquel emerge una y otra vez como el responsable, en cualquier nivel de su conciencia o inconsciencia, de que las ideas digan lo que digan, crezcan o disminuyan, se crucen o se repelan. La polifonía es, por ello, una técnica que no puede borrar el hecho de que el gesto semántico del «autor» determine los discursos, los argumentos y las ideas. Así pues, lo que diferencia lo monológico de lo dialógico no es la autonomía de las voces (inexistente en realidad), sino la técnica y el modo de representación utilizados.

Hay un momento en el que Bajtín expresa de una forma muy clara esa falta de autonomía de las voces enfrentadas. Cabe que no se trate, como en el resto de los casos, de una intención expresa en la dirección de su argumentación. De hecho, se encuentra en el capítulo que funciona como introducción a su libro: «La novela polifónica de Dostoievski y su presentación en la crítica». El fin de todo ese apartado es el de presentar la polifonía, la 
pluralidad de voces, las conciencias independientes, como principal rasgo estructural de la obra de Dostoievski. Hablando en concreto de la autonomía del discurso del héroe respecto al autor escribe Bajtín:

En sus obras aparece un héroe cuya voz está formada de la misma manera como se constituye la del autor en la novela de tipo común. El discurso del héroe acerca del mundo y de sí mismo es autónomo como el discurso normal del autor, no aparece sometido a su imagen objetivada como una de sus características, pero tampoco es portavoz del autor, tiene una excepcional independencia en la estructura de la obra, parece sonar al lado del autor y combina de una manera especial con éste y con las voces igualmente independientes de otros héroes (Bajtín, 1993: 17) ${ }^{12}$.

Tanto la versión española (lengua término) como la rusa (lengua de partida) se preocupan mucho de establecer que el personaje «parece sonar al lado del autor» (оно звучит как бы рядом с авторским). Donde el ruso dice «como si» (как бbl), el español (Tatiana Bubnova) dice «parece». Tanto en un caso como otro se trasluce que Bajtín no puede afirmar con contundencia la independencia del personaje en relación al autor. El «como si» (как быl) implica un grado de fingimiento semejante a la situación en que alguien se comporta «como si» fuera alguien o supiera algo, pero que ni es ese alguien ni sabe ese algo. Marlon Brando hace «como si» fuera Marco Antonio en el film Julio César (1953) de Mankiewicz, pero Marlon Brando no es Marco Antonio. De igual manera, el personaje habla «como si» fuera independiente del autor, pero en realidad no lo es. El «parece» de la traducción española revela con justeza lo que sucede: que la supuesta independencia del personaje respecto al autor es un recurso técnico y estructural puesto al servicio de la construcción de un modelo de mundo.

Un modelo que Bajtín definirá de un modo que nos resulta familiar: el mundo como carnaval, «el pathos de cambios y transformaciones, de muerte y renovación» (Bajtín, 1993: 175). No es poco significativo que Bajtín se refiera a ese «mundo» en términos de un «principio unificador que relacio-

12 Ofrezco en nota al pie las palabras del texto tal y como fue escrito por Вajtín: «В его произведениях появляется герой, голос которого построен так, как строится голос самого автора в романе обычного типа. Слово героя о себе самом и о мире так же полновесно, как обычное авторское слово; оно не подчинено объектному образу героя как одна из его характеристик, но и не служит рупором авторского голоса. Ему принадлежит исключительная самостоятельность в структуре произведения, оно звучит как бы рядом с авторским словом и особым образом сочетается с ним и с полноценными же голосами других героев» (1979: 209). 
naba los más variados elementos en un todo orgánico del género» (Bajtín, 199: 189). ¿No resulta sintomática y contradictoria esta convivencia de la polifonía y el todo orgánico?

Tal y como se puso de relieve en anteriores trabajos (Asensi, 2011), el silogismo afectivo propio de la «literatura» (lo que allí se denominó mediante el neologismo afepto), así como los modelos de mundo a los que da lugar, no se sitúan en el plano del contenido, no dependen de lo que en términos tradicionales podría llamarse «significado», sino que se presentan totalmente unidos al plano de la expresión, son en ese sentido un efecto del significante con el que están relacionados de forma íntima. Dicho de otro modo: el recurso a la polifonía, a las voces y conciencias enfrentadas, son el plano de la expresión, el recurso técnico, que da lugar al modelo de mundo carnavalesco que puso en juego Dostoievski. Así pues, la independencia del personaje con respecto al autor queda seriamente puesta en tela de juicio.

¿Por qué si no iba a escribir Bajtín ese «como si» (как бы), ese «parece» de la traducción española, si de cierto la conciencia del personaje fuera independiente de la del autor?

La atención que Bajtín presta al «diálogo socrático» como antecedente histórico de lo carnavalesco, resulta llamativa y sorprendente. ¿Se adecua a la realidad una afirmación como la que sigue?:

Las ideas de Sócrates, de los sofistas principales y de otros personajes históricos no se citan ni se reproducen aquí, sino que se dan dentro de un desarrollo libre y creador junto con otras ideas que las dialogizan (Bajtín, 1993: 158).

¿De verdad Bajtín piensa que Critón, Górgias, Fedro, Adimanto o Protágoras, son conciencias independientes del modelo de mundo expuesto lógicamente por Platón al socaire de Sócrates? ¿No serán la síncrisis y la anácrisis (Bajtín, 1993: 156) de nuevo los recursos técnicos empleados por Platón para exponer el modelo de mundo de la filosofía platónica? Por mucho que Bajtín asegure que los protagonistas del diálogo socrático son ideólogos (Bajtín, 1993: 157) ${ }^{13}$, y que sus ideas circulan libremente, el lector o lectora siempre tiene la impresión de que los contrincantes de Sócrates son las marionetas empleadas por Platón para acabar determinando el lugar de una verdad monolítica con pocos resquicios. Va de suyo que esto no supone de-

13 La cursiva es del autor. 
fender que la filosofía platónica sea simple, esté libre de problemas epistemológicos, o no tenga aporías o contradicciones internas, pero sí que los personajes de los diálogos socráticos sufren el manejo de Platón conducente a cimentar los planteamientos socráticos.

Hay un pasaje en el diálogo «Gorgias» en el que, casi de una forma auto-reflexiva, se pone de manifiesto el marionetismo a que están sometidos los personajes. En un tono que, sin duda, es irónico y cuyo origen se halla en la avalancha de preguntas a las que Calicles se ve sometido por Sócrates, tiene lugar el siguiente diálogo:

Cal. - ¡Qué tenaz eres, Sócrates! Si quieres hacerme caso, deja en paz esta conversación o continúala con otro.

Sóc. - ¿Qué otro quiere continuarla? No debemos dejar la discusión sin terminar.

Cal. - ¿No podrías completarla tú solo, bien con una exposición seguida, bien preguntándote y contestándote tú mismo? (505d).

El pasaje resulta delicioso por cuanto Calicles revela una verdad contundente, que es, a la vez, el gesto auto-reflexivo e irónico de Platón respecto a sus supuestos «diálogos». La insistencia de Sócrates preguntando y preguntando, llevando a un callejón sin salida, a Calicles, hace que este desvele un hecho fundamental y metadiscursivo: en realidad Calicles, Querofonte, Polo o Gorgias son los apoyos en los que descansa el discurso socrático, que, en todos los sentidos posibles, es monológico y no dialógico. Por eso le reprocha que podría completar él solo la conversación y responderse a sí mismo. Es que en verdad Sócrates habla solo y contesta él mismo a todas las cuestiones, por mucho que ponga en boca de algún sofista preguntas y respuestas. Todo el libro de Bajtín es un esfuerzo, en varias direcciones sincrónicas y diacrónicas, de fundamentar una polifonía que no es sino un recurso más puesto al servicio de la creación de modelos de mundo.

Con razón hace notar el teórico ruso al hacer el recorrido histórico por los antecedentes de la novela polifónica que toda su investigación se mueve en el nivel de las suposiciones: «Este no es el lugar para comprobar todas las aseveraciones histórico-literarias que hemos planteado. No importa que queden a nivel de suposiciones» (Bajtín, 1993: 269). La profundidad y la lucidez demostradas por Bajtín le llevan, en ocasiones, a correr riesgos como los señalados en los que sus planteamientos encuentran límites importantes. Uno de ellos podría quedar resumido así: la independencia de las voces en relación al autor es un entimema que enmascara el carácter exclusivamente técnico de dicha polifonía. Esta posee el carácter de una estrate- 
gia puesta al servicio de lo que el propio Bajtín describe como «visión del mundo» de Dostoievski, la cual recorre por entero la investigación que lleva a cabo sobre la obra de este autor.

Aunque asegure que «una tarea polifónica es incompatible con el planteamiento unívoco de una sola idea» (Bajtín, 1993: 112), no puede sino reconocer que para Dostoievski no existe «ni el pensamiento aislado, ni la unidad sistemática. Para él, la última unidad indivisible no era un pensamiento aislado, limitado por su objeto, ni un postulado, o una aserción, sino un punto de vista íntegro» (Bajtín, 1993: 133). Sin embargo, se podría objetar que un modelo de mundo donde reine el conflicto y la divisibilidad infinita, debida a la presencia de lo ajeno, no es menos modelo de mundo que una aserción o un pensamiento aislado. Entre uno y otro hay una diferencia de modelos de mundo, pero su cualidad de modelo de mundo es innegable. La «lógica ambivalente del carnaval», definitoria de la obra de Dostievski, es un modelo de mundo en contraste con otros modelos de mundo, pero no por ello menos «modelo de mundo».

Se podrá estar más o menos de acuerdo con la interpretación freudiana de la obra del escritor ruso, desde luego no representa el mismo avance en el ámbito de la investigación literaria que supuso la obra inmensa de Bajtín; pero, sin embargo, Freud no cayó en el error que venimos señalando. Freud fue plenamente consciente de que los movimientos de los personajes de una novela como Los hermanos Karamazov están en una relación de dependencia respecto a Dostoievski. Cuando afirma que:

El parricida es, en efecto, otro hermano, al que Dostoievski atribuye singularmente su propia enfermedad, la pretendida epilepsia, como si quisiera confesar que el neurótico y el epiléptico que en él había era un parricida (Freud, 1981: 227).

Está dando en el clavo, no porque acierte en la complejidad del modelo de mundo de Dostoievski, sino porque tiene claro que esos hermanos Karamazov forman parte del teatro de marionetas del así llamado «artista».

\section{REFERENCIAS BIBLIOGRÁFICAS}

ADLAM, C. (2000). The Annotated Bakhtin Bibliography. Leeds: Maney for the Modern Humanities Research Association.

ASENSI, M. (2011). Crítica y sabotaje. Barcelona: Anthropos/Siglo XXI. 
ASENSI, M. (2012). «Los CSI y la guerra de Arguedas (en torno al silogismo del discurso en el pensamiento de la crítica como sabotaje)». En Bolognese, Ch., Bustamante, F. y Zabalgoitia, M., Éste que ves engaño colorido... Literaturas, culturas y sujetos alternos en América Latina, 57-84. Barcelona: Icaria.

- (2013), «Modelos de mundo y lectores/as desobedientes». Anthropos. Cuadernos de cultura crítica y conocimiento 237, número monográfico coordinado por Beatriz Ferrús y Mauricio Zabalgoitia con el título La crítica como sabotaje de Manuel Asensi, 17-30.

BAJTÍN, M. (1985). Estética de la creación verbal. México-Madrid-Buenos Aires-Bogotá: Siglo XXI. Edición rusa de 1979.

- (1989). Teoría y estética de la novela. Madrid: Taurus. Edición rusa de 1975.

- (1993). Problemas de la poética de Dostoievski. Buenos Aires: FCE. La edición rusa original es de 1963 en su segunda versión; la primera era de 1929. La que manejamos aquí es la siguiente: М.М.Бахтин. Проблемы поэтики Достоевского. Moskva: Sovetskaya Rossiya Izdatelstvo, 1979.

BENNET, T. (1978). «Bakhtin's historical poetics». En Formalism and Marxism. London: Methuen.

BIALOSTOSKY, D. H. (1986). «Dialogics as an art of discourse in literary criticism». PMLA 101. 5, 788-797.

DERRIDA, J. (1967). La voix et le phénomène. Paris: PUF.

- (1981). Espolones. Los estilos de Nietzsche. Valencia: Pre-Textos. La ed. original francesa es de 1978.

DOMÍNGUEZ CAPARRÓS, J. (1993). «Algunas ideas de Bajtín sobre la autobiografía». En Escritura autobiográfica, José Romera Castillo et alii (ed.), 177-186. Madrid: Visor Libros.

FERRÚS, B. (2013). «¿¿Sólo a mí me estorban los libros para salvarme?’, Sor Juana Inés de la Cruz, crítica como sabotaje, feminismo e historiografía literaria». Antropos. Cuadernos de cultura crítica y conocimiento 237, 99-112.

FREUD, S. (1981). Psicoanálisis del arte. Madrid: Alianza Editorial.

GARDINER, M. (1992). The dialogics of critique. M. M. Bakhtin and the theory of ideology. London-New York: Routledge.

GENETTE, G. (1989). Figuras III. Barcelona: Lumen. La edición original francesa es de 1972. 
GUIRAUD, P. (1969). Essais de stylistique, problèmes et méthodes. Paris: Klincksieck.

HAYNES, D. J. (2013). Bakhtin reframed. London: I. B. Tauris.

HITA JIMÉNEZ, J. A. (2002). «Revisión del concepto de polifonía en la crítica literaria rusa». Mundo eslavo: revista de cultura y estudios eslavos $1,99-108$.

HOLQUIST, M. (1990). Dialogism. Bakthin and his Wordl. London and New YorK: Routledge.

KOZHINOV, V. (1993). «Algunas palabras acerca de la vida y la obra de Bajtín». Introducción al libro de Bajtín, 1993, 7-13.

LACAN, J. (1983). Escritos 1. México: Siglo XXI, 10. a ed.

LÁZARO CARRETER, F. (1953). Diccionario de términos filológicos. Madrid: Gredos.

MORRIS, P. (ed.) (1994). The Bakhtin Reader. Selected Writings of Bakhtin, Medvedev, Voloshinov. London-New York: Arnold.

MUKAROVSKY, J. (1977). Escritos de estética y semiótica del arte. Barcelona: Gustavo Gili.

PONZIO, A. (1998). La revolución bajtiniana: el pensamiento de Bajtín y la ideología contemporánea. Valencia: Universitat de València.

RIVERO GARCÍA, I. (2003). «Intertextualidad, polifonía y localización en investigación cualitativa». Athenea Digital: revista de pensamiento e investigación social 3, 1-13.

ROMERA CASTILLO, José et alii (eds.) (1995). Bajtín y la literatura. Madrid: Visor Libros.

SADIKOV, A. В. (2010). Новый Испанско-Русский Словарь Современного Употребления/Nuеvo Diccionario Español-Ruso de Uso Moderno. Moscú: Russki Yazik-Media.

SHKLOVSKI, V. (1983). O teorii proziy. Moskva: Izdatelstvo Sovetski Pisatel.

STALLINGS, G. C. (2013). «Modelos musicales: Manuel Asensi, Haruki Murakami». Antropos. Cuadernos de cultura crítica y conocimiento 237, 171-182.

STEINBY, L. (2013). Bakhtin and his Ohers: (Inter)subjectivity, Chronotope, Dialogism. London: Anthem Press.

THOMSON, C. (1984). «Bakhtinian methodologies». Semiotic Inquiry/ Recherches Sémiotiques 4 (3): 372-387. 
TODOROV, T. (1965). Théorie de la littérature (textes des Formalistes russes réunis, présentés et traduits par Tzvetan Todorov. Paris: Seuil.

VALDÉS BUBNOVA, T. (2006). «Voz, sentido y diálogo en Bajtín». Acta Poética 27 (2), 135-154.

VOLOSHINOV, Valentin N. (1992). El marxismo y la filosofía del lenguaje. Madrid: Alianza Universidad. La obra se editó en ruso en 1929.

Recibido el 8 de junio de 2013.

Aceptado el 19 de septiembre de 2013. 